\title{
FEATURE Hugh Hammond Bennett and the creation of the Soil Conservation Service
}

\author{
Douglas Helms
}

This article is a continuation of the historical developments discussed in "Hugh Hammond Bennett and the creation of the Soil Erosion Service," Journal of Soil and Water Conservation, Volume 64, Number 2, pages 68A-74A.

The article discusses the events of September 19, 1933, to April 27, 1935, during which time Hugh Hammond Bennett and colleagues in the Soil Erosion Service (SES) established demonstration projects. The young agency weathered questions about their authority to work on private lands. The USDA and state agricultural institutions argued that this work belonged in USDA. Throughout the controversies, the cadre of soil conservationists won approval in the countryside and thereby built support in Congress for expansion of the soil conservation work on a permanent basis. The pending expiration of SES's emergency employment funding in June 1935 gave an air of urgency to legislation for a permanent agency. Finally, drought in the Great Plains and dust clouds sweeping eastward to the federal city dramatically demonstrated the need for soil conservation.

ugh Hammond Bennett's appointment as director of the Soil Erosion Service (SES) became effective September 19, 1933, and he moved to the US Department of the Interior (USDI) offices in the Winder Building, 600 17th Street, NW, in Washington, DC. In taking his leave from the Department of Agriculture, Bennett wrote to thank Assistant Secretary of Agriculture Rexford Tugwell for all the "interest you have taken in my behalf in connection with the erosion program" (Bennett 1933a). Bennett also reported on assembling the Soil Erosion Service staff. He had written to Walter Lowdermilk inviting him to join the

Douglas Helms is the National Historian at the USDA Natural Resources Conservation Service, Washington, DC. new service. Tugwell met Lowdermilk in California and had recommended him to Bennett (Helms 1984; Lowdermilk 1969). Bennett asked Tugwell for the assistance of several erosion experiment station directors to start demonstration projects. This first request was for the assistance of H.V. Geib of the Blackland Station, Texas; G.W. Musgrave of the Missouri Valley Station, Iowa; W.A. Rookie of the Pacific Northwest Station, Washington; R.E. Uhland, of the Missouri Station, Missouri; and R.H Davis of the Upper Mississippi Valley Station, Wisconsin.

Bennett also tried to convince Tugwell to correct a situation that had vexed him since the creation of the erosion experiment stations-joint supervisions of a number of stations. He built his case by recounting the recent history of the soil conservation movement. Bennett had been the driving force behind securing the Buchanan Amendment in 1929 to fund soil erosion experiment stations. However, the Chief of the Bureau of Chemistry and Soils (BCS) included the Forest Service and Bureau of Agricultural Engineering (BAE) as operators of some stations. The Forest Service operated stations alone, while the BCS and the BAE jointly supervised some stations. As Bennett wrote to Tugwell, “... out of that move a tremendous amount of grief has originated" (Bennett 1933a).

Bennett thought that the Forest Service had achieved results, "all of which we have appreciated as much as they" (Bennett 1933a). The engineers, agronomists, and soils scientists had also "obtained basic information that we should have had 75 years ago..." (Bennett 1933a). Yet, Bennett firmly believed much more could have been achieved except for the tensions between the BCS agronomists and BAE agricultural engineers. The latter had kept up "an almost running attack of criticism of this or that agronomic experiment installed at my direction" (Bennett 1933a). At the most extreme he said some of his opponents held that "erosion can be controlled by terraces and only by terraces" (Bennett 1933a).
A North Carolinian, Bennett knew terraces had been used in the South for a century, and the Mangum terrace, developed by a North Carolina farmer, had been in use for a half-century. He conceded the benefits of terracing on gentle slopes where the soils were not erodible. Bennett placed the emphasis, however, on vegetation and soil tilth. He opined to Tugwell, "soil erosion control on cultivated land is essentially an agronomic problem" (Bennett 1933a). He urged Tugwell to place supervision of all of the erosion experiment stations exclusively under the Bureau of Chemistry and Soils.

As director of SES, Bennett began implementing the plan that he had earlier presented to Secretary of Interior Harold Ickes on September 16, 1933. He thought the most effective results could be achieved if the demonstration projects worked in large areas, preferably complete watersheds of 25,000 to 300,000 acres. The projects should be aligned with watershed boundaries so as to show the cumulative effects of soil conservation, including "flood prevention." Bennett intentionally used the term "flood prevention" to distinguish this result from structural "flood control." Furthermore, he believed that, "The probability is that these effects are going to be much greater than any one has supposed" (Bennett 1933b). These projects would be located in approximately 20 regional soil erosion areas that Bennett had identified. There were already 12 soil erosion experiment stations in these regions, and now he proposed to add the action, or demonstration, phase of the plan.

The first projects would be near the experiment stations where the directors of the stations could implement the lessons learned from the experiments. The station directors would have to locate a nearby watershed where a significant number of farmers showed an inclination to sign an agreement and work with the new service. A staff consisting of some combination of agronomists, soil scientists, engineers economists, and biologists would be assembled to implement the project, and depending on the location, a forester or 
range specialist would be included. Most of the watershed-based projects took the name of the water body and were numbered sequentially. Raymond H. Davis, superintendent of the Upper Mississippi Valley station at La Crosse, Wisconsin, was the first experiment station director to secure the cooperation of farmers in a nearby watershed. Thus, nearby Coon Creek was designated project number 1 in November, and by January 1934, project number 10, the Navajo Project, was established. The original $\$ 5,000,000$ had been allocated at this point.

About two months after arriving in the Department of the Interior, Bennett beseeched Ickes for funds to establish another 12 or 13 projects in addition to the 12 projects to which the initial $\$ 5,000,000$ had been allocated. Five or six of the projects would be devoted to research and others to demonstrational models. To bolster his arguments, Bennett told Ickes that, "Dr. Tugwell of the Department of Agriculture and others have suggested that the Soil Erosion Service look into the probability of obtaining additional funds for erosion-control projects..." (Bennett 1933c). Unquestionably, Bennett also wanted to expand the program. A serious question remained as to whether there were sufficient specialists with the interest and experience in soil conservation to staff the projects. After some inquires, Bennett believed he could enlist qualified staff. Most of the proposed projects would be outside the agricultural regions covered by the soil erosion experiment stations. The conservation methods would have to be determined as work commenced. The second $\$ 5,000,000$ became available in March 1934. SES established another 14 projects by late April 1934, at which time the second $\$ 5,000,000$ had been allocated (USDOI 1934).

Since the initial funding of the Service, the emphasis in New Deal emergency work programs had shifted. Bennett submitted this request to Ickes in midNovember, 1933, and the Civil Works Administration (CWA) had been established on November 9, 1933. The CWA reflected President Roosevelt's (FDR) preference for work relief over direct unemployment relief. As unemployment threatened to rise in the winter of 19331934, Harry Hopkins presented FDR with

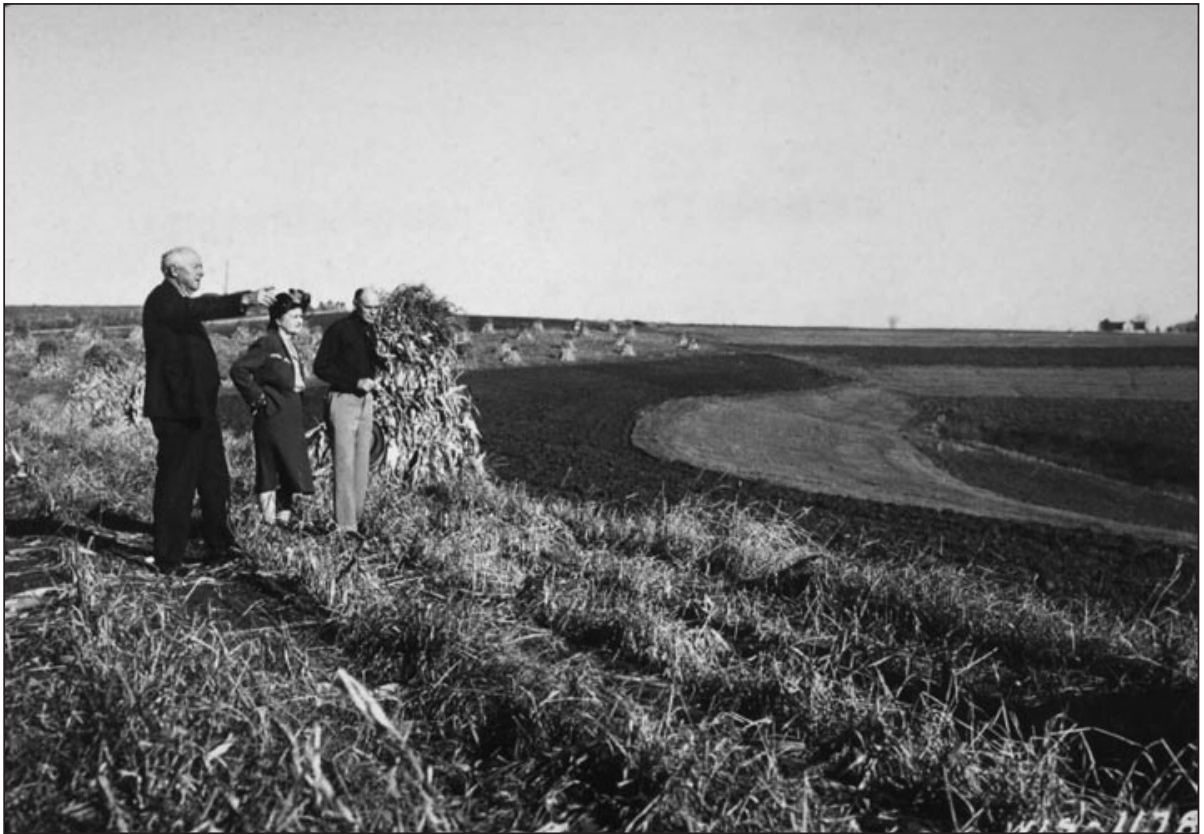

Chief Hugh H. Bennett, Mrs. Bennett, and regional conservator A. E. McClymonds view conservation work on the Frank Milsna farm, Manske Ridge, Vernon County, Wisconsin, which is on the Coon Creek Demonstration Project. Photo courtesy of the USDA Natural Resources Conservation Service, Madison, Wisconsin.

a plan to pay for CWA out of the Public Works Administration funds. The mission of the CWA was to provide employment and to provide it quickly. Ickes suggested that Bennett contact Hopkins about funding the additional SES projects, and Bennett did so (Ickes 1933). Wanting to provide immediate employment for the winter, CWA established strict criteria. Projects must be ready to put the unemployed to work in 15 days, and the projects had to be finished by February 15. New SES demonstration projects could not meet this schedule (Bennett 1933d).

Bennett explained the situation to Ickes and pointed to the urgent need as demonstrated by the many requests arriving daily by "letter, telegraph, long distance telephone and delegations" for additional projects (Bennett 1933d). He recounted the destruction erosion had wrought and made his plea. "We simply can not afford to lose this most indispensible asset of the country, but we will lose it unless vastly more is done from now on than ever has been done along the line of conserving good agricultural land" (Bennett 1933d). Bennett saw no other alternative than to seek another allocation from the Public Works Administration appropriation.

Once again Bennett was persuasive. Ickes, however, needed the President's approval. Within the week, Ickes was scheduled to join FDR at his Warm
Springs, Georgia, retreat and would seek his approval there. The President granted the additional $\$ 5,000,000$ with the stipulation, in Ickes words, that "the work to be paid out of this sum not to start until the C. C. C. camps move north next spring“" (Ickes 1933a). The statement about the Civilian Conservation Corps (CCC) camps was important in that it signified that President Roosevelt expected SES to use corps enrollees.

While new demonstration projects would not be established with CWA funds, the CWA supplied a great many workers for SES projects during winter and spring 1934. They were instrumental in what was perhaps SES's first large-scale foray into dam building. Project number 25, the Gila Project in Arizona, was a new type of work for SES. SES built thousands of dams or water retarding structures of varying sizes on the tributaries to reduce floods and store sediments. This type of upstream flood control would become prevalent after Congress assigned flood control authorities to the Soil Conservation Service. The $8,200,000$ acres project, mainly in the upper Gila River watershed, was second in size only to the 16 million acre Navajo Project (Bennett 1934a).

Soon SES would no longer have CWA funds due to yet another shift in New Deal work relief policy in 1934. Despite the plight of the unemployed, work relief had 
not been universally accepted in the countryside or in Congress. Within the New Deal administration, opponents of deficit spending for work relief, especially FDR's budget director, inveighed against it. FDR, at least temporarily, relented, closed CWA, and transferred the remaining funds to the Emergency Work Relief Program of the Federal Emergency Relief Administration (FERA). A critical result of the demise of CWA and reinvigoration of FERA was that FERA only financed state-initiated projects, not federally initiated and controlled projects (Schlesinger 1958).

As CWA closed its door, Bennett turned to FERA with his case for assistance for soil conservation. FERA, created by the Federal Emergency Relief Act of May 12, 1933, provided money to states to hire the unemployed. Harry Hopkins continued as FERA administrator during the time he also headed the CWA. SES staff prepared a plan requesting FERA labor for established demonstration projects, but was told that all projects needed approval by each FERA state administrator. After the initial rebuff, Ickes advised Bennett to meet personally with Hopkins. While Hopkins seemed sympatric, he deferred to his staff, who would not deviate from the policy that all projects had to be state initiated (Bennett 1934b).

The news would only get worse. Bennett began to receive letters from his field staff that some states were gearing up for FERA-funded terracing efforts. The complex of land-grant colleges, state agricultural experiment stations, and state extension services usually applied for these projects. The development had echoes of the conflicts leading up to the creation of the Soil Erosion Service. Bennett felt it was time to inform the Secretary, lest the growth of disparate state FERA-funded terracing only projects undermined the national soil conservation effort. $\mathrm{He}$ recounted to Ickes the persuasive case that had been made for setting up SES:

When the matter of the use of Public Works funds for erosion control first came to my attention it was presented as a program essentially identical with this present proposed program of FERA. Dr. Tugwell asked me what I thought of it. I told him frankly what I am briefly telling you in this memorandum, giving him the proof of the futility of any such

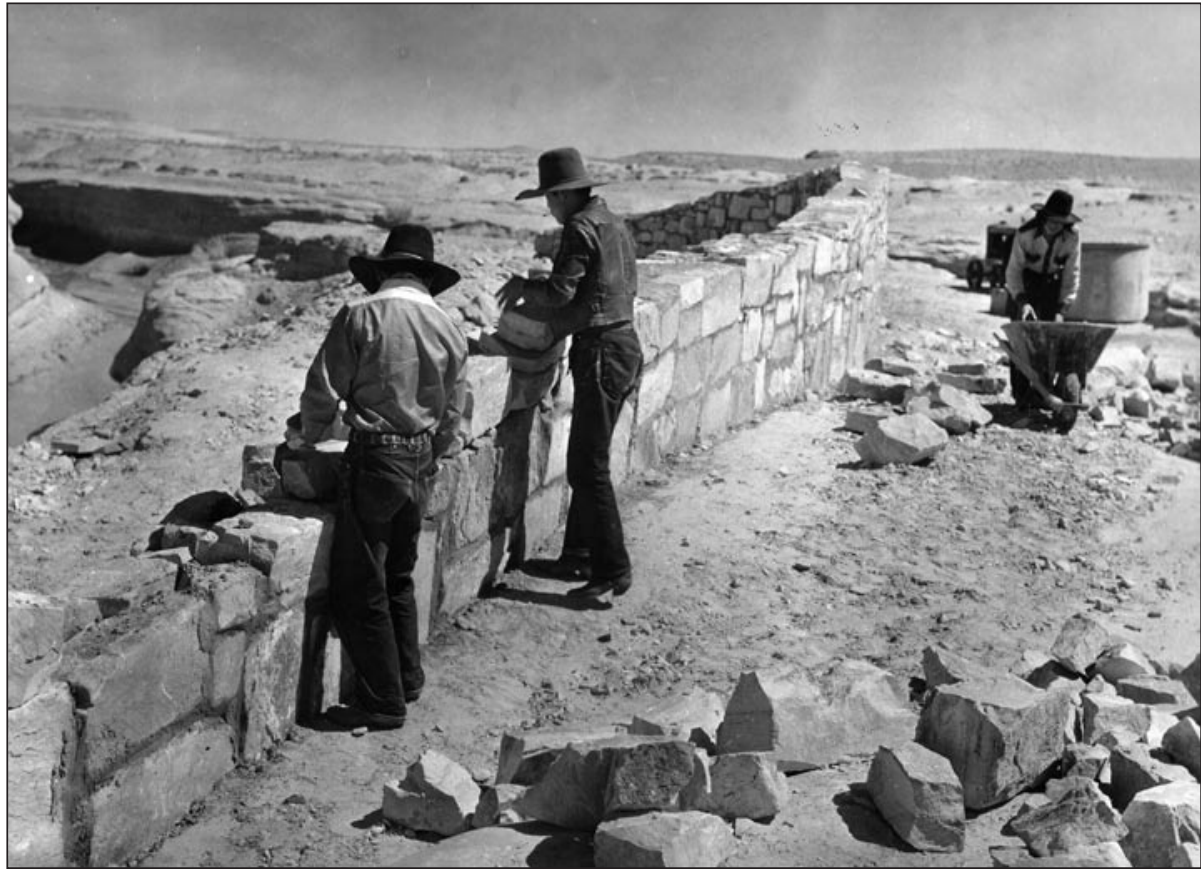

Navajo Civilian Conservation Corps workers build a diversion. Navajo Nation, Tuba City, Arizona. Photo 75 N-Nav-296 from the National Archives, College Park, Maryland.

single-track method of undertaking to control a great national problem involving numerous variables, such as soil, slope, type of agriculture, and rainfall. I think he discussed the matter with you and that you or he discussed it with the President. At any rate, I was informed by Dr. Tugwell the President felt that the best way to attack the program was to select representative watersheds in various parts of the country, and on these carry through a complete, impressive job of erosion control, such as would arouse the land owners of the country to the practical possibilities, not only of directly curbing erosion, but through this control reduce the hazards of floods and silting of stream channels and reservoirs. Accordingly, the strictly engineering proposal was laid aside and this complete, correct land-use and land-protective program which the Soil Erosion Service is now engaged in was adopted. There is no question about the success of this present program, if it is not undermined in the manner mentioned above. (Bennett 1934a)

In late 1934 , Bennett was also becoming concerned that the Forest Service seemed to be expanding its soil erosion camps. By September 1934, there were 161 such camps whose work was actually planned and supervised by the state agricultural agencies. Bennett wanted SES to direct these camps and called upon Rexford
Tugwell and E. K. Burlew, special assistant to Secretary Ickes, to assist in advancing this effort (Bennett 1934c).

The origins of these camps lay in the need to locate CCC camps east of the Rocky Mountains. While there was support for CCC investments in federal lands, the potential for investing public funds on private lands was not met by some with enthusiasm. During the deliberations over the act creating the CCC, officially the Emergency Conservation Work, Robert Y. Stuart, chief of the Forest Service, asked that state and private land also be made eligible as work areas. Otherwise, enrollees from the East would have to be transported west of the Rocky Mountains, where 95\% of the public domain lay. Stuart's argument was persuasive in part. The Act for the Relief of Unemployment allowed soil erosion control work on state and federal land, but restricted work on private land to activities already authorized under US laws, such as controlling fire, disease, and pests in forests and "such work as is necessary in the public interest to control floods" (Statutes at Large 1933). On the day Roosevelt signed the bill, Secretary of Agriculture Henry A. Wallace wired each governor to send a representative to Washington to discuss cooperation on forestry work. He also mentioned the flood control work and surmised that it "probably [included] control of soil erosion" (Helms 1985). 
President Roosevelt and other New Dealers remained concerned about the appearance of spending public money on private land. He told a USDA representative that he wanted CCC work on erosion and flood control directed to solving flooding problems over broad areas rather than benefiting an individual parcel of land. CCC Director Robert Fechner reiterated the president's reservations about work on private land to the governors in May 1933. Concern about the public's objections to expenditures of federal funds on private lands caused some of Roosevelt's reservations. He continued to warn Fechner that too much work on private land would bring criticism. Also, Roosevelt, like many of his contemporaries, too often thought soil conservation required shifting cropland to woodland and was unfamiliar with the many conservation practices that could be installed on cropland with CCC labor. However, he also had to heed the calls for a full share of CCC camps in those states with small public land holdings. Thus, Roosevelt asked Fechner and Wallace to grant requests for soil erosion control camps.

Within USDA, the Forest Service administered the erosion camps similarly to its state and private forestry work. Under signed agreements, personnel from state agencies and land grant colleges actually operated the camps. CCC efforts followed soil erosion control guidelines established by USDA that limited work to controlling gullies by means of soil-saving dams, forest planting and vegetation. Gradually, the concept was extended to include construction of terrace outlets. This was hardly the approach utilizing agronomic and other integrated methods that Bennett envisioned. While still in USDA, Bennett advised the Forest Service on work of the soil erosion camps (Helms 1985).

WhenBennettmoved to the Department of the Interior, he tried to have the soil erosion CCC camps transferred to SES. SES did acquire the aid of some CCC camps when they moved north in the spring of 1934 as the President had stipulated. Ickes forwarded SES's requested for 53 camps or approximately two camps per demonstration project to Robert Fechner, director of the Emergency Conservation Work, in February 1934 (Ickes 1934a). Fechner assigned 22 camps to SES on April 1,1934.

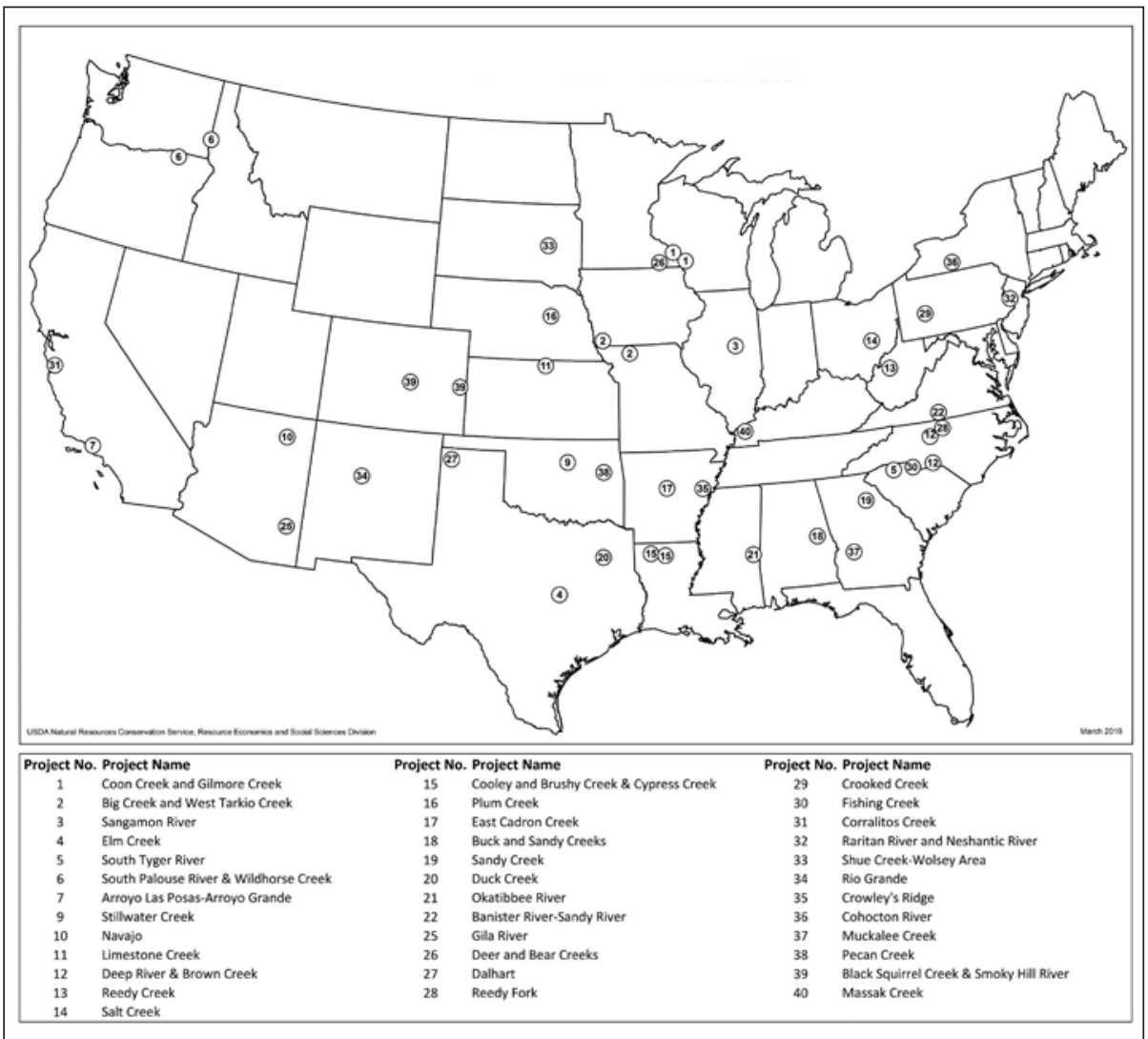

Soil Erosion Service demonstration projects, 1933 to March 1935. Image courtesy of the USDA Natural Resources Conservation Service, Soil Survey Division, Washington, DC.

Simultaneously SES was losing the labor of CivilWorks Administration workers, which was available from December 15, 1933, to May 1, 1934. By June 1934, another 29 CCC camps, including some dedicated to drought-relief, would be assigned to SES, making a total of 51. CWA and CCC labor gave SES a persuasive tool in working with farmers. Demonstration projects could control gullies, fence and establish pastures, build terrace outlets, and lay out contour stripcropping. Despite this boost to Bennett's program, SES faced several unforeseen threats in second half of 1934. The issues revolved around SES's authority to work on private land, expenditures for fencing, and the growing terracing program funded out of the FERA. These interrelated issues roiled simultaneously in the second half of 1934.

\section{PUBLIC LAND DEMONSTRATION PROJECTS}

The resolve of John Collier, Commissioner of Indian Affairs, to improve the land conditions on the Navajo Reservation had led him to Hugh Hammond Bennett in mid1933. After the Navajo Council approved the plan proposed by Bennett, work began immediately on the research station at Mexican Springs, New Mexico. After SES was created in the Department of the Interior, Bennett established the 16 million acre Navajo Project in the first group of projects. To augment the work being done on the Navajo Project, Bennett also proposed a Rio Grande Demonstration Project that included both public and private land. Much of the valuable private land was in the Rio Grande River drainage. Except for the Zuni Pueblo, the Rio Grande River drained all of New Mexico's Pueblo Indian lands. Spanish villages dotted the Rio Grande and its tributaries north of Albuquerque. The earliest villages predated the English settlement at Jamestown. Rectangular fields lay perpendicular to the streams giving all farmers access to the water. Over three centuries, the strips narrowed as heirs subdivided the land. Planning for the project would take into account "the human factors involved in the Spanish and Indian civilizations" (Bennett 1934d). SES would hire anthropologists to study how to most effectively bring conservation to the Spanish villages. The need to understand the human aspects in order to make conservation effective led 
to the original studies that are the foundation of applied anthropology in the United States (Bennett 1934d; Kelly 1985).

The Rio Grande was the 34th project established, and another six would be added by the time SES was transferred to USDA, although a number of projects were never fully implemented or were projects in name only and not actual demonstration projects. The Tennessee Valley Authority Project, number 8, was never fully implemented since the Authority chose to work with farmers through the state agricultural institutions rather than SES. Projects numbered 23 and 24 were actually the national soil erosion surveys headquartered at Pennsylvania State College and Cornell University, and while they were implemented, they were not demonstration projects in collaboration with farmers.

\section{DEMONSTRATION PROJECT FOR THE SOUTHERN GREAT PLAINS}

The dust storms of 1933 were localized in the Southern Great Plains, but in 1934, a large dust cloud ascended over the plains. Carried by the westerly winds, it attracted national attention. On May 11, 1934, it swept fine soil particles over Washington, DC, and 300 miles out into the Atlantic Ocean. Bennett seized the opportunity to explain the cause and offer the solution. Confidently, he touted the need for soil conservation and predicted future trouble if changes were not made in land use and farming practices. The New York Times quoted him on May 14, 1934, as saying, "Now, we have the evil with us on an enormous scale, and the nation may as well gird tightly its belt for a continuing battle against this process of land wasting, that is if we are to avoid the eventuality of becoming probably the world's most outstanding nation of subsoil farming-which of course generally means bankrupt farming on bankrupt land" (New York Times 1934). In the future, when discussing the edifying aspect of that storm, Bennett quickly reiterated that it was SES which "centered attention not only upon the cause, but upon the cure of these destructive phenomena" (USDA SCS 1935). It went without saying that Bennett was the agency's primary spokesman.

In May 1934, as Bennett publicized the dust storms in the press, he also moved to set up a demonstration project in the yet to be named Dust Bowl. At Bennett's request, Dr. H.V. Geib, the regional director at the Blacklands erosion experiment station in Temple, Texas, submitted a plan for a 16-square-mile demonstration project. Bennett forwarded the plan to Ickes for approval and made the case to Ickes:

If the project could be put over successfully, as I believe it can, we would have demonstrated that wind erosion can be successfully controlled, and will have pointed the way to the prevention of this phenomenon which is so seriously affecting the agricultural and grazing lands of the western Mississippi Valley. (Bennett 1934e)

Bennett did not ask for additional funds and believed that the $\$ 35,000$ needed could be scraped together out of existing SES funds. Without delay, Ickes approved the project on May 29, 1934 (Bennett $1934 \mathrm{e})$.

None of the original demonstration projects had been located in the area that would become known as the "Dust Bowl." In fact, Bennett's 1933 regional erosion map, compiled before wind erosion swept the area, had not included the area of the coming Dust Bowl. In the late 1920s, as Bennett worked with the states to select

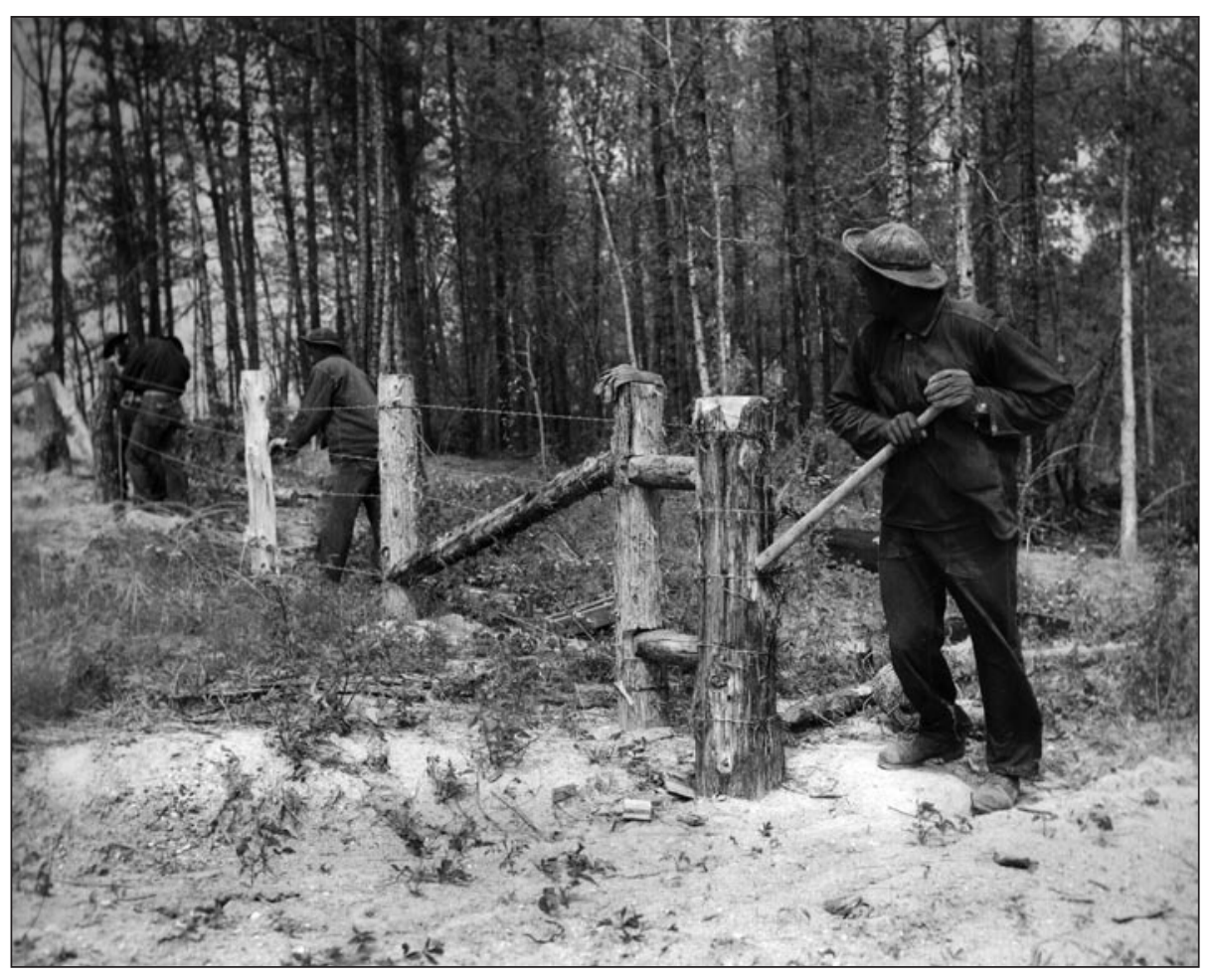

Civilian Conservation Corps enrollees building fences. Camp SCS-NC-5, Yanceyville, North Carolina.

Photo 35G-287 from the National Archives, College Park, Maryland.

sites for erosion experiment stations, they established one at Guthrie, north of Oklahoma City, to serve the "red plains." Cotton growing was the primary cause of erosion in the area. The demonstration project at Stillwater Creek, on the edge of the "red plains," was in the first group of projects established. One of Bennett's respected allies from the early soil conservation movement, Nathaniel Winters of the nearby Oklahoma A.\&M. College, directed it. Following Ickes approval, Bennett enlisted H.H. Finnell, then director of Panhandle A\&M Experiment Station at Goodwell, Oklahoma, to establish the demonstration project at Dalhart, Texas.

\section{ISSUE OF WORK ON PRIVATE LANDS}

Accomplishments at the demonstration projects were impressive, creating a clamor for additional projects. However, Bennett's Soil Erosion Service had a key hurdle to overcome-work on private land complicated the situation. Many people supported CCC and WPA work on national parks, national forests, public buildings, roads, and other public infrastructure. Such work seemed a clear-cut case of spending public funds for public benefits. FDR, and Ickes to an even greater extent, feared the negative perceptions that could accompany the 
expense of public funds for private benefit. Thus, the proposed work of the Soil Erosion Service on private farmland came under scrutiny. More so than the use of WPA and CCC labor, government purchases of supplies used on farms were examined closely. One of the triumphs of the soil conservation movement under Bennett would be the public acceptance of soil conservation as a public benefit and worthy of the expense of public funds. This concept was not universally accepted in the early New Deal.

Ickes disliked his moniker, "Honest Harold," but it indeed correctly characterized his aversion to the actuality or perception of the misuse of public funds. In April 1934, Ickes notified Bennett of "grave doubt" concerning the amount of money spent on and the policy of working on private lands. He directed Bennett to make no further commitments for work on private land (Ickes 1934b). The instruction shocked Bennett. The legislation funding SES has seemed clear on the issue. In appealing to Ickes, he used the example of public funds for soil surveys made on private lands. Landowners could then use the information for private benefit. While assuring Ickes that his instructions would be followed, he made the case that federal work on private land was critical to halting soil erosion:

Private land owners could not carry through the necessary educational, demonstrational and experimental work, even if they had the funds. They do not know how...I am so deadly in earnest about the absolute necessity of carrying on this work as a matter of vital national economy.... (Bennett 1934f)

By mid-May of 1934, the Solicitor of the Department ruled that the work on privately owned land was legal. The imbroglio was settled, at least temporarily, just as the dust storm of May 11, 1934, reached the east coast, bringing with it more attention to soil erosion. Nonetheless, Ickes wanted work restricted as much as possible to public lands (Bennett 1934g).

Later in 1934, Ickes became alarmed over the issue of fencing. In late October of 1934, he ordered Bennett to stop expenditures "on fences or other improvements..." However, expenditures were permitted on "the plantings or materials necessary to prevent or correct actual erosion itself" (Ickes 1934c). Bennett explained to Ickes that fences were needed to protect the vegetation while the gullies were being stabilized. They were also essential to the land use adjustments on individual farms. The demonstration projects had been placed in cropland areas with severe erosion and where a major objective was the conversion of cropland to pasture. He elaborated as follows:

If there were any possible way in which we could induce the farmers to construct the necessary fencing, I would agree that they should do so. The simple fact is that on most of our areas the farmers are so poor that they cannot possibly afford to bear all the expense of such construction. Preliminary results obtained from economic surveys indicate that in many instances farm incomes are as low as $\$ 100$ per family per year and that generally incomes are astoundingly low. Under these circumstances, it is impossible to persuade cooperating farmers to construct fences at their own expense and at the same time to remove from agricultural use the areas being fenced, thus reducing their apparent incomes. (Bennett 1934h)

To placate Ickes, Bennett proposed a clause in the cooperative agreement stating that "all fence materials provided to the Cooperator at the expense of the Government under this Agreement will remain the property of the United States, which reserves the right to remove such materials when they have served their purpose...." (Soil Erosion Service 1935). In the interest of promoting the conversion of cropland to pasture, SES supplied seed and fertilizer. Bennett tried to head off this issue by advising field staff to keep these purchases to the minimum "necessary for effective and complete demonstrations" (Soil Erosion Service 1935). Project directors should make the point that expenditures on private land were for demonstrations and educational purposes rather than direct aid to landowners (Soil Erosion Service 1935).

\section{SPECIAL COMMITTEE ON SOIL EROSION}

Ickes was conflicted. He wanted the soil conservation work to succeed and admired Bennett's persistence when not exasperated by it. Yet, he was determined that his stewardship of the Department of the Interior would not be tainted by misuse of funds or corruption. He appointed a Special Committee on Soil Erosion to advise him on future policy, including the private lands issue. Ward Shepard, a professional forester, chaired the committee. After a long career in the Forest Service, Shepard was hired by John Collier to assist in the reform of the Bureau of Indian Affairs. Another committee member was Charles F. Shaw, a professor of soil science at the University of California and former employee of the Bureau of Soils. Shaw cowrote the 1905 soil survey of Robertson County, Texas, with Bennett.

During the committee's deliberations, Bennett received an inquiry from Fred E. Schnepfe, Director of the Planning and Federal Projects Division of the Federal Emergency Administration of Public Works, as to why SES had not reached their assigned goal of hiring 5,000 workers. Bennett immediately brought the contradiction to Ickes's attention-SES was going to have to lay off workers due to the private land ruling, while another arm of government demanded more public employment (Bennett 1934i). Through special assistant E.K. Burlew, Ickes asked Bennett's forbearance and explained his thinking. He wrote to Burlew as follows:

I wonder if you can persuade Bennett to let me alone until we have had a report from the men who are surveying his Division? I don't want to hold up any work that he can legitimately do and I don't want him to have to lay men off, but, on the other hand, I don't want to permit the use of public funds for improper purposes. I wish there were some way of getting the answer to this whole question as soon as possible because if he is on the right track, he ought to be permitted to go ahead. (Ickes 1934d)

The committee issued a preliminary report that work on private land was legal and necessary. Solicitors of USDI and USDA had already ruled that work on private lands was permissible. The committees' full report recommended that new projects be limited to 25,000 acres and that the Soil Erosion Service be transferred to USDA.

In transmitting the report, Shepard referred to Bennett's "magnificent work" as 
a "brilliant opportunity for the beginning of a permanent attack on soil erosion...." (Shepard 1934).The opportunity should be seized. The committee strongly endorsed Bennett's comprehensive approach. The CCC and FERA should provide labor and not operate their own programs. Finally, Shepard offered a rebuke to his former employer when he wrote, "the Forest Service, in developing a large CCC erosion control project on private lands, is getting completely outside the domain of forestry" (Shepard 1934).

With the preliminary report of the Soil Erosion Committee in hand, Bennett and colleagues recommended another seven projects to Ickes for funding in late December 1934. The projects were drawn from over 100 applications and most fell within the 25,000-acre limitation recommended by the committee. Ickes approved the projects on January 7, 1935, while the funding was set to expire in June 1935, the second anniversary of the passage of the National Industrial Recovery Act (Bennett $1934 j$ ). These projects would have only a six-month lifespan unless something was done to give SES new life.

\section{TRANSFER TO USDA}

With SES funding due to expire in June 1935 , discussion of the future of SES accelerated. Wallace and Ickes exchanged letters arguing over the transfer of SES to USDA. The President brought up the possibility of such a transfer at a Cabinet meeting in early March 1935. Ickes objected and thought he would have an opportunity to make his case before the President took any action. At a later meeting, also in March, Ickes left believing he had the President's approval to draft legislation to create a permanent soil conservation agency in Interior and to have that legislation introduced by Congressional allies (Ickes 1953). Ickes was already receiving requests from Congress for assistance in drafting legislation. Bennett, Lowdermilk, and the Department of the Interior's legal staff were working on legislation (Ickes 1935a).

Ickes forwarded to Donald Richberg, Executive Director of the National Emergency Council, proposed legislation that provided for soil conservation and authorized the President to coordinate the soil conservation activities of all Federal agencies. Since Richberg knew that the institutional location of the SES was under discussion, he arranged a meeting with the President. FDR and Richberg met on February 9, 1935, and Richberg left believing that FDR had told him that all Federal soil erosion work should be consolidated in USDA (Richberg 1935a). Given the President's decision, Richberg sought the advice of USDA on the legality of the proposed legislation. Seth Thomas, Solicitor of USDA, concluded that the President, by executive order, could not consolidate all Federal soil erosion control activities in USDA. Legislation would be required. The President could, however, by executive order, transfer the Soil Erosion Service to USDA. Secretary Wallace concurred (Richberg 1935b).

Allocation of CCC camps for the fifth enrollment period, April 1 to September 30, 1935, added another element of urgency to the decision about SES's future. Walter Lowdermilk, SES's assistant director and who handled CCC matters, had requested 533 camps. Director Robert Fechner, on March 9, 1935, allocated 570 units for the Soil Erosion Service but pending "the decision of the President as to the manner in which Soil Erosion Work is to be supervised in the future" (Fechner 1935).

\section{DUST STORM OVER EAST COAST}

A yellow haze appeared over Washington before noon on March 6, 1935. The Weather Bureau reported that pilots observed thick dust at 8,000 feet elevation above Bolling Field, south of the Capitol. Bennett turned his pen to the event and explained the source of the dust to readers of the Washington Post's Sunday edition. Employing his descriptive powers, Bennett wrote "To Washington and the urban East last week came a grim and graphic reminder of calamity in the rural West. Tons of dirt - topsoil from the windswept fields of Kansas, Colorado, Texas, and Oklahoma-appeared suddenly in the sky above the cities of the Atlantic seaboard, hovered pall-like for a day, and then passed slowly on to be dissipated somewhere over the ocean" (US Congress. House 1935).

Thursday, the day after the dust storm, Henry Wallace wrote to the President trying to prompt a decision. Earlier that week, House Agriculture Committee
Chair, Marvin Jones, had telephoned the Secretary saying he was prepared to introduce a bill to create a permanent soil conservation agency in the US Department of Agriculture. Jones wanted to be in step with the President's plans and asked Wallace's guidance. Jones, who had been chairman of the House Agriculture Committee since March 1931, represented Amarillo in the Texas panhandle, the area soon to be dubbed the "Dust Bowl" by a Washington journalist. Wallace asked Jones to delay while he consulted the President.

Wallace essentially made the argument to FDR that the "work of the Soil Erosion Service is excellent but it is largely agricultural ...." (Nixon 1957). Were it to remain in Interior, eventually there would be political difficulties with the agricultural establishment. Wallace told the President that Ickes probably recognized these realities but regarded SES as "good trading stock" in his plan to create a Department of Conservation that would include the national forests, then under the Forest Service in USDA.

Wallace concluded with an appeal to avoid disruption in the President's larger agenda:

I know you don't want any fights within your family and I am sure that I don't want any disagreement within the progressive segment of the family; nevertheless, I am certain that inasfar as the Department of Interior deals with agricultural matters and with farmers, there is likely to be eventual serious trouble. (Nixon 1957)

FDR read the letter on Friday, March 8, 1935 , and appended the following note for the assistant secretary in charge of appointments, Marvin McIntyre:

I want to see Mr. Bennett of the Soil Erosion Service. Make an appointment for Monday for me and I want to have this to take up with him when he comes. (Roosevelt 1935a)

\section{BENNETT'S MEETING WITH FDR}

Evidently McIntyre did not give Bennett notice of the meeting on Friday or over the weekend. Bennett's article on the dust storm appeared in the Sunday edition of the Washington Post, March 10, 1935. Late on the morning of Monday, March 11, Bennett received a call from the office of Marvin McIntyre to come to the White 
House prepared to discuss the allocation of Civilian Conservation Corps camps to SES. Walter Lowdermilk had developed the recent request for 533 camps that had been submitted to Robert Fechner, director of the Emergency Conservation Work. Since Lowdermilk knew the details of the camp request, Bennett asked if Lowdermilk could accompany him. The two had only a short time to gather up a few maps and rush to the White House. After discussing this matter with Donald Richberg, Chair of the Emergency Council, Bennett was asked to go in to see the President.

The President said numerous requests were coming to him to transfer SES to the Department of Agriculture. FDR implied that this acquisitiveness by others was surely the best endorsement of the quality of SES's work. The President inquired whether Bennett was averse to transferring to USDA. Upon returning to his office, Bennett, his memory fresh, recounted the conversation in a memorandum to Ickes:

My replies to questions asked in this connection were much in line with those which I recently made to you; namely, that we had made great progress in the Department of the Interior, we had been treated nicely, were satisfied to remain in the Department and that you had taken great pains to help us. In answer to the question as to whether I had any strong objection to the Department of Agriculture, my reply was to the effect that I had no antipathy toward that Department, but I did suggest that in case it should be decided that the Soil Erosion Service would be transferred to that Department it was my feeling that those parts of various organizations carrying on direct erosion control work should be transferred to the Soil Erosion Service. (Bennett 1935a)

FDR did not tell Bennett what he planned to do, nor did he act immediately. Tugwell confided in his diary that at their March 14 meeting, FDR pledged to write a letter to Ickes that afternoon; yet, he delayed (Tugwell 1935). Events in Congress eventually nudged FDR into action. Marvin Jones kept his pledge to Wallace not to introduce his bill, favorable to USDA, until the President had made a decision. Others, however, were not waiting. Congressman John C. Nichols of Oklahoma, Congressman John J. Dempsey of New Mexico, and Congresswoman Isabella S. Greenway of Arizona, introduced H.R. 6432, H.R. 6439 and H.R. 6440 , respectively, to create a soil conservation agency.

\section{DUST STORM OVER THE CAPITOL AND} CONGRESSIONAL HEARINGS

On March 20, 1935, hearings on the proposed legislation commenced in a subcommittee of the House of Representatives' Committee on Public Lands. On March 20th, the opening day of the hearings, FDR wrote to Ickes announcing his decision. True to his word, the President assured Ickes that Bennett had not initiated this meeting. He wrote, "Mr. Bennett is most appreciative of the splendid cooperation which he has had from the Department of the Interior, and I want to make it perfectly clear to you that he has not in any shape, manner or form, advocated a transfer of the Soil Erosion Service to the Department of Agriculture" (Roosevelt 1935b). The President had decided that as a matter of "function" the Soil Erosion Service belonged in USDA. When the hand-carried letter arrived at the Department of the Interior, the staff notified Ickes, who was reviewing the Seminole Reservation in South Florida. On March 21, 1935, Secretary Ickes sent a telegram to the President pleading his case and reminding the President of the pledge of a personal hearing before the final decision was made. He wrote, "Notwithstanding your memorandum on this subject I hope that I may be heard on this subject before final order is entered" (Ickes 1935b). Roosevelt would not relent, but offered an explanation. "I would certainly have waited in the matter of the Soil Erosion Bureau except for the fact that a very difficult situation started to come to a head on the Hill" (Roosevelt 1935c).

As the hearings on the soil conservation bills opened, the wind erosion season of 1935, February through April, was in full force. A telegram from Frank L. Duley, director of the demonstration project at Mankato, Kansas, to the SES Washington DC office announced that "Dust storms (are an) almost daily occurrence in Western Kansas" (Duley 1935). The 1935 blow season proved to be the worst of the thirties drought. On March 20, the day a dust storm swept over Kansas, Roosevelt's

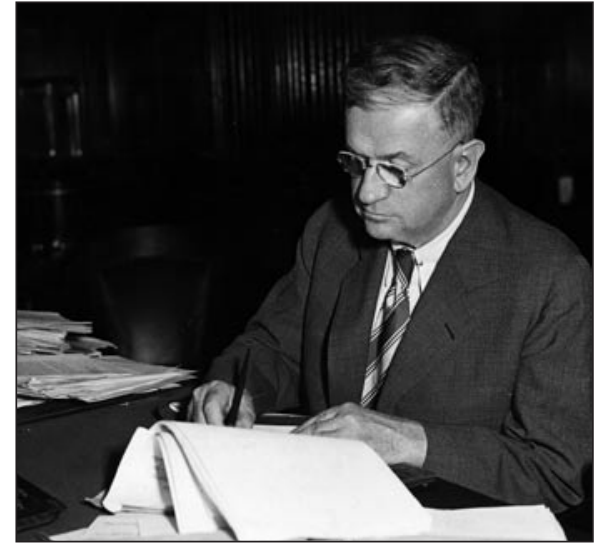

Secretary of Interior Harold Ickes at his desk. Photo RG208-PU-98K-6 from National Archives, College Park, Maryland.

future Presidential challenger, Governor Alf Landon, telegrammed FDR asking for Federal assistance and declaring, "This catastrophe is of such size and importance that it is more than the problem of a single state" (Landon 1935). Soon Landon would be in Washington to organize support of the Congressional delegation from the Plains states for a relief program. The storm on March 20 reduced visibility in Kansas City to two blocks. The Kansas highway patrol stopped traffic to prevent accidents. The storm crossed Kansas at an estimated 35 miles an hour and crossed the Mississippi River at Quincy, Illinois, in early evening (New York Times 1935). Heavier soil particles dropped out while the finer particles were carried higher into the faster moving jet stream. As the cloud swept eastward, it appeared higher on the horizon, rather than as a darkening storm at ground level.

Hearings on the soil conservation bills before a subcommittee of the House Committee on Public Lands opened on March 20 with Hugh Hammond Bennett testifying primarily on water erosion. Bennett certainly knew of the dust storm approaching from the Midwest when the hearings continued on March 21. That morning's Washington Post carried an article describing the conditions on March 20 in Midwestern cities. Also, Soil Erosion Service field offices had kept Bennett informed of dust storms by telegram, and had mailed local newspaper articles (Telegrams 1935). When Bennett resumed his testimony on the second day, March 21, he inserted into the record that morning's Washington Post article, his Post article of March 10 detailing the March 6 
dust cloud over Washington DC, and other recent newspaper articles from the Midwest and Great Plains cities (US Congress. House 1935).

Bennett opened his testimony with a discussion of the clouds that passed over Washington DC on May 11, 1934, and March 6, 1935. The transcript for March 21 makes no note of the arrival of the dust cloud, but arrive it did. The center passed north of Washington DC, but it was clearly visible in the Washington DC on March 21. The Washington Post reported "Throngs of curious persons, leaving Government offices, swarmed down the Mall and to Potomac Park, where the dust was visible" (Washington Post 1935b). Most accounts of events in the hearing room are secondhand, based on conversations with Bennett. Some of the details and embellishments conflict with the actual events. There are few first-hand accounts by Bennett.

North Carolina State College invited Bennett to deliver a series of lectures, near the end of his life. Recounting the successful campaign for a soil conservation agency, he recalled, "There were other incidents, such as the timely arrival of a dust storm during the Committee hearings" (Bennett 1959). He seldom elaborated in writing and left the door open to confusion. Biographers Jonathan Daniels and Wellington Brink place the dust cloud event during hearings of the Senate Committee on Public Lands. The Senate hearings actually were held by the Committee on Agriculture, while the House of Representatives hearings were held before the Committee on Public Lands. The dust cloud of March 20 in the Midwest and its arrival over Washington DC on March 21 was well documented in newspapers. Weather observations for the East Coast and Washington newspapers did not report a dust cloud over Washington during the Senate hearings in April 1935 (Daniels 1941; Brink 1951).

Down Pennsylvania Avenue at the White House the transfer of SES unfolded. The President acted on the day after the arrival of the dust cloud. At noon, March 22, 1935, Marvin McIntyre telephoned Oscar Chapman, Assistant Secretary of the Department of the Interior to say, "The President is instructing you to call a special meeting of the Public Works Board to pass the resolution on the transfer of the Soil Erosion Service." Chapman protested that

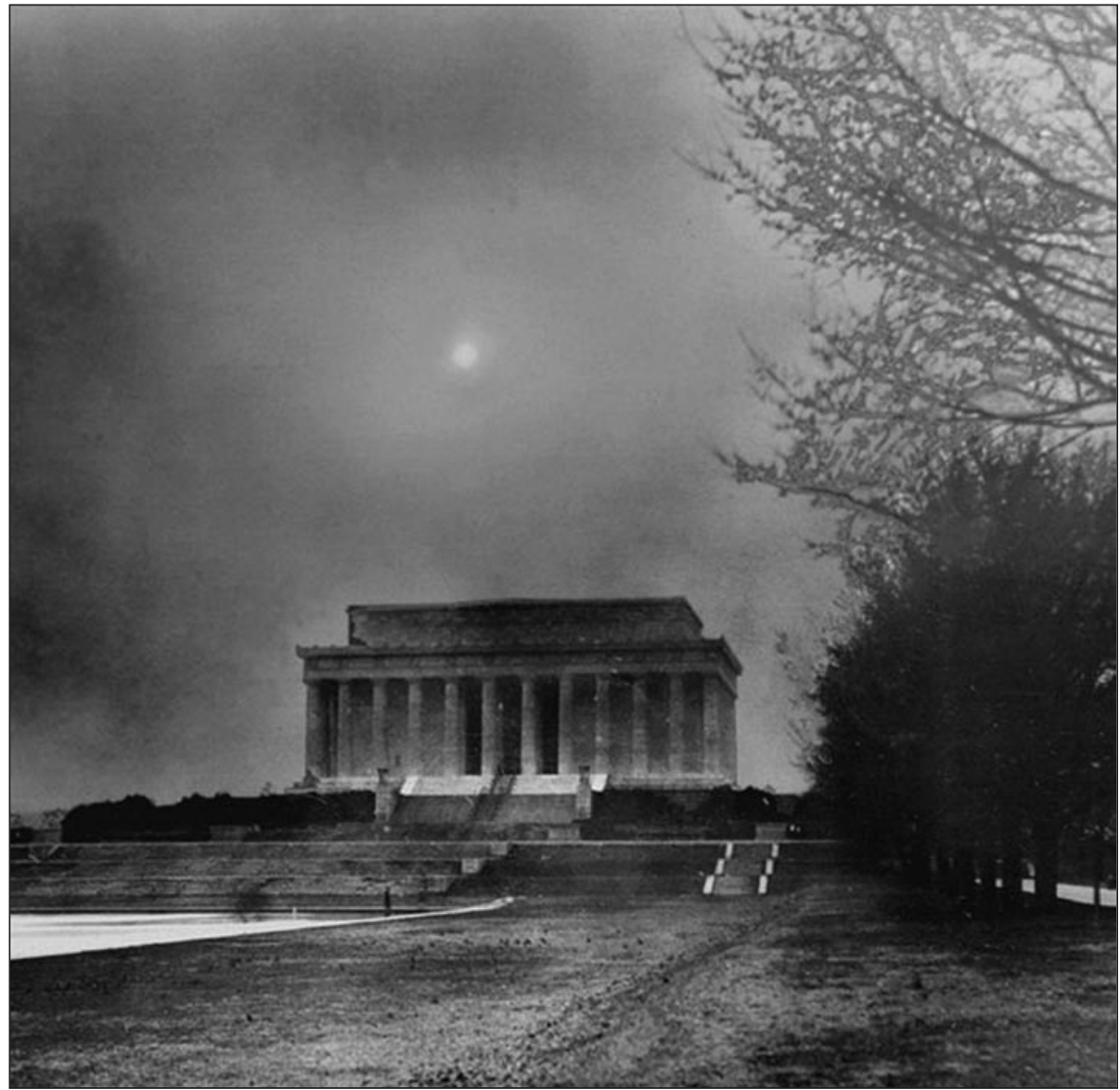

Dust reaches Washington DC, Spring, 1935. Photo RG 114G-c-6001a from the National Archives, College Park, Maryland.

the Secretary was out of town, to which McIntyre replied: "Yes, the President knows that." Chapman offered to get the board together the next day, only to be told, "Can't you do it immediately? The President wants it done now, today." Chapman called Ickes, asking what to do. Ickes already knew of the President's decision. "You have to do what he tells you," advised the Secretary (Telephone transcripts 1935). The Interior staff notified the members of a 4:00 p.m. meeting that day. Later that day, the Public Works Board executed the transfer order, which FDR signed on March 25.

The House hearings concluded on March 25 and the Committee reported out H.R. 7054 with amendments on March 29. After the House debated and passed H.R. 7054 on April 1, the Senate Committee on Agriculture and Forestry held hearings on April 2 and 3, 1935, and reported out their amended bill on April 11. The Senate committee amended the bill by adding the word "permanently" to the statement of policy and included "public health" as an objective. Also the amendment specified that the agency would be known as the Soil Conservation Service (US Congress. Senate 1935).

Meanwhile, dust storms kept national attention on the plains. On April 14, 1935, (Black Sunday), the most awesome of the black blizzards, driven by 60 miles per hour winds, struck without warning. Total darkness prevailed in Dodge City, Kansas, for forty minutes. The black blizzard traveled the 105 miles between Boise City, Oklahoma, and Amarillo, Texas, in one hour and fifteen minutes. In Guymon, Oklahoma, the reporter Robert Geiger penned an article for the Washington (DC) Evening Star in which he used the term "Dust Bowl." It stuck (Hurt 1935).

The Senate debated and passed H.R. 7054, with the Senate amendments, on April 15, 1935. The next day, Senator William Henry King of Utah made a motion to reconsider. His objective was to assign the new agency to the Department of the Interior. Failing to attract enough support, he withdrew the motion on April 19. The House concurred in the Senate amendments on April 23. After 
Department of Agriculture officials reviewed the bill, President Roosevelt signed Public Law 46 of the 74th Congress on April 27, 1935 (Nixon 1957).

\section{CONCLUSION}

In retrospect, passage of the legislation was hardly a predictable outcome, despite Bennett's intense desire for such an agency. Consider the obstacles. The funding was temporary and set to expire in June 1935, less than two years after commencement of the work. Labor for the projects was uncertain, as the administration waffled between their hope that the depression would end soon and their full embrace of public employment programs. Then there were the competitors: the terracing projects under the Federal Emergency Relief Administration, the CCC erosion camps of the Forest Service, and the emerging plans of the Agricultural Adjustment Administration to add a soil conservation component to their price-support programs.

These hurdles were counterbalanced in part by Ickes's support of legislation to create a soil conservation agency in his contemplated Department of Conservation. Reflecting on the early history, Bennett thought it was probably a good idea SES got its start in Interior and recalled that Ickes "invariably came to the assistance of his bureaus in arguments originating outside the Department" (Bennett 1959). Though Bennett had not been Rexford Tugwell's first choice as Director of the Soil Erosion Service, he remained a supporter and advisor who had access to the President as a member of the Brain Trust. Bennett's concept of a comprehensive approach to soil conservation found favor with Tugwell and Secretary of Agriculture Wallace. They simply held that the soil conservation program belonged in USDA and they would support Bennett once he arrived in the department.

Bennett was the critical element to the successful creation of a federal Soil Conservation Service. He had the ability, whether by dint of personality or experience, to persist without alienating others. Faced with an obstacle, he explained and educated, often in lengthy memoranda, and did not succumb to burning bridges with those whose support he needed or might need in the future. Though occasionally exasperated, Ickes learned to admire his dedication and relentlessness. Bennett was perhaps the only career civil servant, without strong personal social and political ties, to create and lead a federal service.

Finally, passage of legislation was not solely a matter of Washington maneuvering. Bennett assembled a capable staff that was committed to the soil conservation ideal. Farmers and their Congressional representatives liked the demonstration projects and requested more. The cause easily elicited congressional supporters nationwide. The dust clouds sweeping eastward were dramatic and lent urgency to the cause of soil conservation, but the intention had always been for a national program. Favorable reviews in the countryside assured passage of the legislation.

\section{ACKNOWLEDGEMENTS}

The author thanks Patricia J. Lawrence, Paul Reich, and Samuel R. Stalcup of the USDA Natural Resources Conservation Service for their assistance.

\section{REFERENCES}

Bennett, H.H. 1933a. Letter to Rexford G. Tugwell. Folder "Erosion," General Correspondence, Record Group 16. College Park, MD: National Archives and Records Administration. September 20, 1933.

Bennett, H.H. 1933b. A Plan for Erosion Control Under the Erosion Section of the Public Works Administration Corporation. File 1-275 Soil Erosion, Central Classified Files, Record Group 48. College Park, MD: National Archives and Records Administration.

Bennett, H.H. 1933c. Memorandum of Inquiry to the Secretary of the Interior With Respect to Advisability of Using Additional Funds for Additional Regional Erosion-Control Projects by the Soil Erosion Service. File 1-275 Soil Erosion, Central Classified Files, Record Group 48. College Park, MD: National Archives and Records Administration. November 23, 1933.

Bennett, H.H. 1933d. Letter to Harold L. Ickes. File 1-275 Soil Erosion, Central Classified Files, Record Group 48. College Park, MD: National Archives and Records Administration. November 23, 1933.

Bennett, H.H. 1934a. Letter to Harold L. Ickes. File 1-275 Soil Erosion, Central Classified Files, Record Group 48. College Park, MD: National Archives and Records Administration. September $18,1934$.

Bennett, H.H. 1934b. A Brief Statement of the Cooperative Activities Carried Out Between the Soil Erosion Service, the Civil Works Administration and the Federal Emergency Relief Administration. File 1-275 Soil Erosion, Central Classified Files, Record Group 48. College Park, MD: National Archives and Records Administration.

Bennett, H.H. 1934c. Bennett to E.K. Burlew, August 11,1934, and Burlew to Bennett,August 16, 1934. File 1-275 Soil Erosion, Central Classified Files, Record Group 48. College Park, MD: National Archives and Records Administration. September $18,1934$.

Bennett, H.H. 1934d. Letter to Harold L. Ickes. File 1-275 Soil Erosion, Central Classified Files, Record Group 48. College Park, MD: National Archives and Records Administration. January 3, 1934 (Approved by Ickes, January 24, 1934).

Bennett, H.H. 1934e. Letter to Harold L. Ickes, Handwritten at bottom of page "Approved, H.L.I.” File 1-275 Soil Erosion, Central Classified Files, Record Group 48. College Park, MD: National Archives and Records Administration. May 29, 1934.

Bennett, H.H. 1934f. Letter to Harold L. Ickes. Folder Soil Erosion, Secretary of the Interior File, 1928-1946, Harold L. Ickes Papers, Manuscript Division. Washington, DC: Library of Congress. April 23, 1934.

Bennett, H.H. 1934g Letter to Hugh H. Bennett. Folder Soil Erosion, Secretary of the Interior File, 1928-1946, Harold L. Ickes Papers, Manuscript Division. Washington, DC: Library of Congress. May 15, 1934.

Bennett, H.H. 1934h. Letter to Harold L. Ickes. File 1-275 Soil Erosion, Central Classified Files, Record Group 48. College Park, MD: National Archives and Records Administration. November 24, 1934.

Bennett, H.H. 1934i. Letter to Harold L. Ickes. File 1-275 Soil Erosion, Central Classified Files, Record Group 48. College Park, MD: National Archives and Records Administration. November 28, 1934.

Bennett, H.H. 1934j. Letter to Harold L. Ickes. File 1-275 Soil Erosion, Central Classified Files, Record Group 48. College Park, MD: National Archives and Records Administration. December $31,1934$.

Bennett H.H. 1935a. Letter to Harold L. Ickes. Folder Soil Erosion, Secretary of the Interior File, 1928-1946, Harold L. Ickes Papers, Manuscript Division. Washington, DC: Library of Congress. March 11, 1935,

Bennett H.H. 1959. The Hugh Bennett Lectures. Raleigh, NC: The Agricultural Foundation, Inc.

Brink, W. 1951. Brink, Big Hugh: The Father of Soil Conservation. New York: Macmillan. 
Daniels, J. 1951. Tar Heels: A Portrait of North Carolina. New York: Dodd, Mead.

Duley, F.L. 1935. Letter to George A. Barnes. File 107.2, General Files, 1933-1935, Record Group 114. College Park, MD: National Archives and Records Administration. March 21, 1935.

Fechner, R. 1935. Robert Fechner, Emergency Conservation Work, to Ferdinand Silcox, Chief, Forest Service,A.B. Cammerer, Director, National Park Service, Duncan K. Major, Jr., Colonel, General Staff, War Department. File OF 6U Soil Erosion, Official File. Hyde Park, NY: Franklin D. Roosevelt Presidential Library. March 9, 1935.

Helms, D. 1984. Walter Lowdermilk's Journey: Forester to Land Conservationist Environmental Review 8(2):132-145.

Helms, D. 1985. The civilian conservation corps: Demonstrating the value of soil. Journal of Soil and Water Conservation 40(2):184-188.

Ickes, H.L. 1933. Letter to Hugh H. Bennett. File 1275 Soil Erosion, Central Classified Files, Record Group 48. College Park, MD: National Archives and Records Administration. November 20, 1933.

Ickes, H.L. 1934a. Letter to Robert Fechner. File 1275 Soil Erosion, Central Classified Files, Record Group 48. College Park, MD: National Archives and Records Administration. February 22, 1934.

Ickes, H.L. 1934b. Letter to Hugh H. Bennett. Folder Soil Erosion, Secretary of the Interior File, 1928-1946, Harold L. Ickes Papers, Manuscript Division. Washington, DC: Library of Congress. April 21, 1934.

Ickes, H.L. 1934c. Letter to E.K. Burlew. File 1-275 Soil Erosion, Central Classified Files, Record Group 48. College Park, MD: National Archives and Records Administration. October 28, 1934.

Ickes, H.L. 1934d. Letter to E. K. Burlew. File 1-275 Soil Erosion, Central Classified Files, Record Group 48. College Park, MD: National Archives and Records Administration. December 1, 1934.

Ickes, H.L. 1935a. Letter to Rufus Poole. Secretary of the Interior File, 1928-1946, Harold L. Ickes Papers, Manuscript Division. Washington, DC: Library of Congress. March 2, 1935.

Ickes, H.L. 1935b. Letter to Franklin D. Roosevelt. File OF 6U Soil Erosion, Official File. Hyde Park, NY: Franklin D. Roosevelt Presidential Library. March 21, 1935.

Ickes, H.L. 1953. The Secret Diary of Harold L. Ickes: The First Thousand Days, 1933-1936. Volume 1. New York: Simon and Schuster.

Kelly, L.C. 1985. Anthropology in the Soil Conservation Service. Agricultural History 59(2):136-147.

Landon, A.M. 1935. Letter to The President (telegram). File OF 732 Soil Erosion, Official
File. Hyde Park, NY: Franklin D. Roosevelt Presidential Library. March 20, 1935.

Lowdermilk, W.C. 1969. Walter Clay Lowdermilk-Soil, Forest, and Water Conservation and Reclamation in China, Israel, Africa, and the United States. Oral History Collection No. 17. Berkeley, CA: University of California, Bancroft Library.

New York Times. 1934. Dust Storms Due to Soil Erosion. May 14, 1934.

New York Times. 1935. Black Dust Storm Chokes Midwest. March 21, 1935.

Nixon, E.B. Jr. 1957. Franklin D. Roosevelt \& Conservation, 1911-1945. Volume 1. Hyde Park, NY: General Services Administration, National Archives and Records Service, Franklin D. Roosevelt Library.

Richberg D. 1935a. Letter to Henry A. Wallace. Folder Erosion, General Correspondence, Record Group 16. College Park, MD: National Archives and Records Administration. February 11, 1935.

Richberg D. 1935b. Letter to Franklin D. Roosevelt. Folder Erosion, General Correspondence, Record Group 16. College Park, MD: National Archives and Records Administration. February 21, 1935.

Roosevelt, F.D. 1935a. Letter to Marvin McIntyre. Note attached to letter of Henry Wallace to Roosevelt, March 7, 1935. File OF 6U Soil Erosion, Official File. Hyde Park, NY: Franklin D. Roosevelt Presidential Library. March 9, 1935.

Roosevelt, F.D. 1935b. Letter to Harold L. Ickes. File OF 6U Soil Erosion, Official File. Hyde Park, NY: Franklin D. Roosevelt Presidential Library. March 20, 1935.

Roosevelt, F.D. 1935c. Letter to Harold L. Ickes. Folder Soil Erosion, Secretary of the Interior File, 1928-1946, Harold L. Ickes Papers, Manuscript Division. Washington, DC: Library of Congress. March 22, 1935

Schlesinger. A.M. 1958. The Coming of the New Deal. Boston, MA: Houghton Mifflin Company. Shephard, W. 1934. Letter to Harold L. Ickes. File 1275 Soil Erosion, Central Classified Files, Record Group 48. College Park, MD: National Archives and Records Administration. December 18, 1934

Soil Erosion Service 1935. Field Order enclosed with Bennett to Ickes. File 1-275 Soil Erosion, Central Classified Files, Record Group 48. College Park, MD: National Archives and Records Administration. January 30, 1935.

Statutes at Large. 1933. 48 Stat. 22.

Telegrams 1935 . These telegrams may be found in file 107.2, General Files, 1933-1935, Record Group 114. College Park, MD: National Archives and Records Administration.

Telephone transcripts. 1935. Folder Soil Erosion, Secretary of the Interior File, 1928-1946, Harold
L. Ickes Papers, Manuscript Division. Washington, DC: Library of Congress. March 22, 1935.

Tugwell, R. 1935. Tugwell Diary, Rexford Tugwell Papers. Hyde Park, NY: Franklin D. Roosevelt Presidential Library. March 14, 1935 ,

US Congress. Senate. 1935. Congressional Record, 74th Cong., 1st sess., 1935, 79 pt. 5:5645.

US Congress. House. 1935. Quoted in US Congress, House, Subcommittee of the Committee on the Public Lands, Soil Erosion Program. Hearings on HR 7054, 74th Cong., 1st. sess., 20, 21, 22, 25 March, 1935.

USDA SCS (USDA Soil Conservation Service). 1935. Report of the Chief of the Soil Conservation Service. Washington, DC: USDA Soil Conservation Service.

USDOI (US Department of the Interior). 1934. Annual Report of the Secretary of the Interior for the Fiscal Year Ended June 30, 1934. Washington, DC: US Department of the Interior.

Washington Evening Star. 1935. Cleveland Has Dust Fall. March 22, 1935, p. A-9.

Washington Post. 1935a. Dust Storms Menace Midwest Wheat Crop-Kansas City ParalyzedDeaths in Scourge Mount to Six. March 21, 1935, p. 1.

Washington Post. 1935b. D.C. Invaded By Dust Storm From Midwest. March 22, 1935, pp. 1 and 5. 